А.А. Бурлака

\title{
Хірургічна тактика при неколоректальних та ненейроендокринних метастатичних ураженнях печінки
}

\author{
Національний інститут раку, Київ \\ Одержано 21.02.2019 \\ Прийнято до друку 11.03.2019
}

DOI: 10.32471/clinicaloncology.2663-466X.38.22206

\begin{abstract}
Досі маловивчена ефективність оперативного лікування метастатичного ураження печінки неколоректальним раком та пухлинами ненейроендокринного генезу (рак нирки, сечового міхура, яєчка, матки та придатків, шлунка, стравоходу, тонкої кишки, легені, меланома шкіри), чиї шляхи гематогенного метастазування не обмежуються тільки системою портальної вени, а поширюються із системним кровотоком. Мета. Виконати ретроспективний аналіз ефективності та безпеки резекцій печінки у хворих із метастазами неколоректального та ненейроендокринного генезу. Об'єкт і методи. Нами проведено ретроспективний аналіз результатів комбінованого лікування онкологічних хворих, які мали в анамнезі метастатичне ураження печінки, на основі бази даних Національного канцер-реєстру Національного інституту раку. Результати. Ретроспективно вивчено 287 випадків хірургічного та комбінованого лікування хворих онкологічного профілю, які мали метастатичне ураження печінки. Пацієнтів умовно стратифікували на 5 груп за морфологічними даними. Найбільшу частку цієї когорти становили пацієнти з онкогінекологічним генезом первинних пухлин $(n=78 ; 27,2 \%)$, хворі на рак молочної залози (n=72; 25,1\%) та група хворих на рак шлунка (n=70; 24,4\%). Найменше хворих було в онкоурологічній групі (n=29; $10,1 \%)$. Також ми проаналізували результати виконання 38 (13,3\%) резекцій печінки, чиї первинні пухлини мали різну локалізацію та гістологічну будову, зокрема рак гортані, трахеї, легені, язика (інші). Медіана загальної виживаності: онкогінекологічна

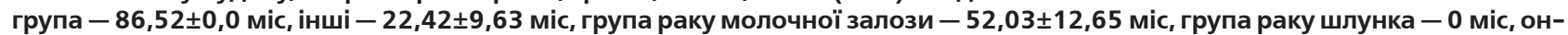
коурологічна група $-50,98 \pm 18,38$ міс. Висновки. Резекції печінки у хворих із ненейроендокринними та неколоректальними пухлинами є доцільними та безпечними. Віддалені результати є морфологічно залежними. Селекція до резекцій печінки у хворих із ненейроендокринними та неколоректальними пухлинами має включати оцінку ефективності системного доопераційного лікування, статус хворого та розбір мультидисциплінарною командою в спеціалізованих хірургічних центрах.
\end{abstract}

Ключові слова: резекції печінки; неколоректальне метастатичне ураження; виживаність.

\section{ВСТУП}

Ефективність та безпека резекцій печінки у хворих на колоректальний рак доведені низкою рандомізованих досліджень, а загальна 5-річна виживаність таких хворих становить 27-65\% [1]. Оперативне лікування при метастатичному ураженні печінки нейроендокринними пухлинами також підвищує виживаність цієї когорти у порівнянні тільки з паліативним системним лікуванням та дозволяє покращити контроль при симптоматичному лікуванні [2]. Тоді як ефективність оперативного лікування з приводу метастатичного ураження печінки неколоректальним раком та пухлинами ненейроендокринного генезу (рак нирки, сечового міхура, яєчка, матки та придатків, шлунка, стравоходу, тонкої кишки, легені, меланома шкіри), чиї шляхи гематогенного метастазування не обмежуються тільки системою портальної вени, а поширюються із системним кровотоком, досі маловивчена.

Тому метою нашої роботи було виконати ретроспективний аналіз ефективності та безпеки резекцій печінки у хворих із метастазами неколоректального та ненейроендокринного генезу.

\section{ОБ' ЄКТ I МЕТОДИ ДОСЛІДЖЕННЯ}

Нами проведено ретроспективний аналіз результатів комбінованого лікування хворих онкологічного профілю, які мали в анамнезі метастатичне ураження печінки, на основі бази даних Національного канцер-реєстру Національного інституту раку. У дослідження включали пацієнтів, яким виконували резекції печінки з приводу ії метастатичного ураження за період із 2010 по 2018 р.

Статистичний аналіз даних проводили за пакетом SPSS Statistics. Нормальність розподілу змінних перевіряли тестом Шапіро - Вілка. За критичний рівень значущості під час перевірки статистичних гіпотез приймали $p=0,05$. Для порівняння незалежних вибірок із ненормальним розподілом викорис- товували тест Манна - Уїтні, а для залежних - Вілкоксона. За критичний рівень значущості при перевірці статистичних гіпотез приймали $\mathrm{p}=0,05$. Виживаність хворих аналізували за методом Каплана - Мейєра.

\section{РЕЗУЛЬТАТИ}

Ретроспективно проаналізовано 287 випадків хірургічного та комбінованого лікування хворих онкологічного профілю, які мали метастатичне ураження печінки. Пацієнтів умовно стратифікували на 5 груп за морфологічними даними. Найбільшу частку цієї когорти становили пацієнти з онкогінекологічним генезом первинних пухлин $(\mathrm{n}=78 ; 27,2 \%)$, хворі на рак молочної залози $(\mathrm{n}=72 ; 25,1 \%)$ та група хворих на рак шлунка $(\mathrm{n}=70 ; 24,4 \%)$. Найменше хворих було в онкоурологічній групі $(\mathrm{n}=29 ; 10,1 \%)$. Також ми проаналізували результати виконання $38(13,3 \%)$ резекцій печінки, чиї первинні пухлини мали різну локалізацію та гістологічну будову, зокрема рак гортані, трахеї, легені, язика (інші) (табл. 1).

Аналіз безпосередніх хірургічних результатів засвідчив, що у більшості хворих виконано R0-резекції - 265 (92,3\%). Також досліджувані групи не мали статистичних відмінностей за загальним рівнем післяопераційних ускладнень та смертності в 30-денний післяопераційний період. Більшість тяжких ускладнень було зареєстровано у хворих, які перенесли великі резекції печінки, у тому числі при мультивісцеральних та комбінованих оперативних втручаннях. Попарний аналіз не виявив статистичних відмінностей між групами за рівнем ускладнень (рисунок).

Віддалені результати оцінені за показниками кумулятивної виживаності та її медіани. Найкращі показники кумулятивної виживаності були у когорти онкогінекологічних хворих

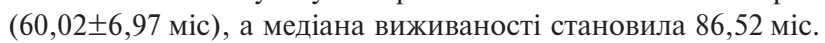
Пацієнти, які були включені в іншу групу, продемонстрували 
Таблиця 1. Характеристика груп хворих

\begin{tabular}{|c|c|c|c|c|}
\hline Групи & $\begin{array}{c}\text { Кіль- } \\
\text { кість (n) }\end{array}$ & $\begin{array}{l}\text { 0б'єм резекції пе- } \\
\text { чінки } \geqslant 3 \text { анатоміч- } \\
\text { них сегментів }\end{array}$ & $\begin{array}{c}\text { Тяжкі } \\
\text { ускладнен- } \\
\text { ня, } \mathbf{n}(\%)^{*}\end{array}$ & $\begin{array}{l}\text { Смерт- } \\
\text { ність, } \\
\text { n (\%) }\end{array}$ \\
\hline $\begin{array}{l}\text { Онкогінеколо- } \\
\text { гічна }\end{array}$ & 78 & $5(6,4)$ & $2(2,5)$ & $1(1,3)$ \\
\hline $\begin{array}{l}\text { Рак молочної } \\
\text { залози }\end{array}$ & 72 & $4(5,6)$ & $1(1,3)$ & - \\
\hline Рак шлунка & 70 & $4(5,7)$ & - & - \\
\hline Онкоурологія & 29 & $2(6,8)$ & $2(6,8)$ & $1(3,4)$ \\
\hline Інші & 38 & $2(5,3)$ & $1(2,6)$ & - \\
\hline $\begin{array}{l}\text { Саркоми } \\
\text { м'яких тканин }\end{array}$ & 7 & - & - & - \\
\hline Рак гортані & 5 & - & - & - \\
\hline Рак трахеї & 4 & - & - & - \\
\hline Рак легені & 7 & - & - & - \\
\hline Рак язика & 3 & 1 & - & - \\
\hline $\begin{array}{l}\text { Меланома } \\
\text { шкіри }\end{array}$ & 12 & 1 & 1 & - \\
\hline $\mathrm{y}_{\text {сьOго }}$ & 287 & 17 & 12 & 2 \\
\hline
\end{tabular}

*Ускладнення शІlla ступеня за шкалою Clavien - Dindo.

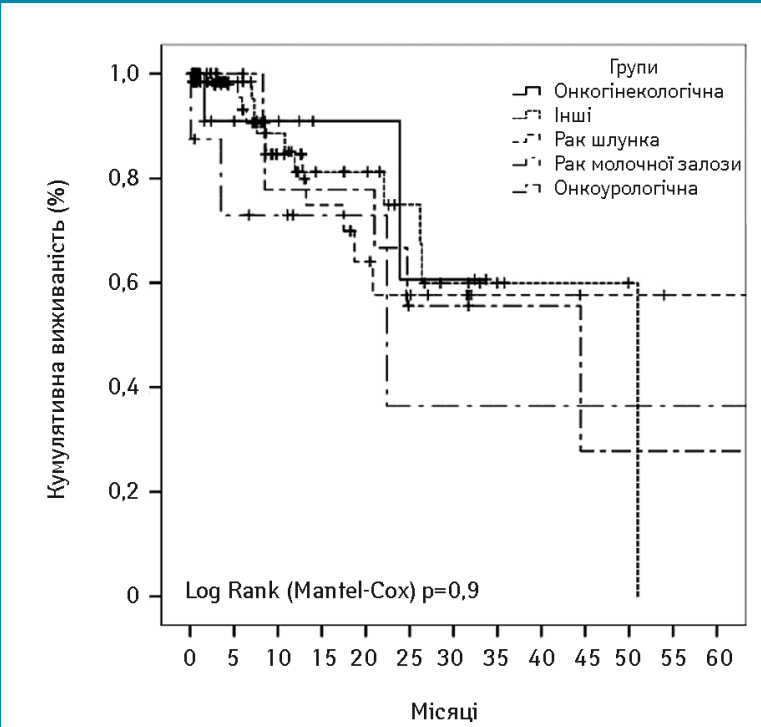

Рисунок. Кумулятивна виживаність досліджуваних груп хворих

середню виживаність, вищу порівняно з рештою груп дослі-

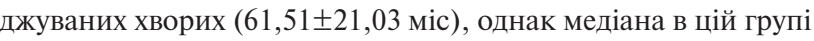
становила тільки $22,42 \pm 9,63$ міс. Останнє можна пояснити нестратифікованими даними за гістологічним діагнозом. Усі досліджувані групи хворих не мали статистичних відмінностей за рівнем середньої кумулятивної виживаності (табл. 2). Пацієнти групи раку шлунка не досягли медіани виживаності на момент проведення аналізу.

У результаті аналізу хірургічного лікування виявлено, що великі резекції печінки найчастіше виконували у групі онкогінекології - 37 (47,4\%). У решті груп анатомічне видалення $\geqslant 3$ сегментів печінки здійснювали рідше, зокрема у групі онкоурології $-7(24,2 \%)$, раку шлунка $-11(15,7 \%)$, раку молочної залози - 14 (19,5\%).

Атипові резекції та анатомічні сегментектомії були основним типом оперативних втручань серед всіх груп хворих. Рідше застосовувалися резекції лівої латеральної секції печінки $45(15,7 \%)$. Великі резекції печінки (видалення $\geqslant 3$ сегментів печінки) були зареєстровані у 17 (5,9\%) випадках. Анатомічну сегментектомію виконали в $26(9,1 \%)$ пацієнтів. Правобічна та лівобічна гемігепатектомії були зареєстровані у $5(1,7 \%)$ та $3(1,1 \%)$ випадках відповідно.

\section{ОБГОВОРЕННЯ}

Декілька багатоцентрових досліджень та метааналізів представили віддалені результати хірургічного лікування хворих із метастатичним ураженням печінки та неколоректальним раком і ненейроендокринними пухлинами, які перебували в межах 27,9-49,3 міс [3]. Усі опубліковані результати хірургічного лікування таких хворих є надзвичайно гетерогенними, існують лише загальні рекомендації щодо застосування резекцій печінки з приводу нейроендокринних пухлин та сарком. В останніх випадках вже доведені доцільність та безпека таких оперативних втручань, що дозволяє покращити віддалені результати у порівнянні із неінвазивними методами лікування до 20-33\% та 46-86\% відповідно [4]. На момент проведення власного аналізу медіана загальної виживаності становила: в онкогінекологічній групі $-86,52 \pm 0,0$ міс, групі інших локалізацій $-22,42 \pm 9,63$ міс, у групі раку молочної залози $-52,03 \pm 12,65$ міс, раку шлунка -0 міс, онкоурологічній групі - 50,98土18,38 міс.

Водночас більшість сучасних публікацій з приводу ефективності хірургічного лікування метастатичного колоректального раку із ураженням печінки демонструють результати, подібні до таких, що були опубліковані за останні 15 років [5, 6]. Якщо не враховувати гетерогенність гістологічних даних, результати хірургічного лікування цієї когорти хворих дозволяють покращити показники загальної 5-річної виживаності в діапазоні 42-50\%.

Незважаючи на той факт, що метастазування пухлини із током крові в печінку є проявом прогресування захворювання, яке, як вважалося раніше, є протипоказанням до хірургічного лікування, комбінація сучасних схем хіміотерапії iз R0-резекцією розцінюється як тактика вибору, яка дозволяє покращити віддалені результати. Застосування резекцій печінки з приводу метастазів неколоректального раку залишається темою для дебатів останні 10 років, з того моменту, як були опубліковані перші наукові праці, що довели його ефективність [7]. Хірургія з приводу метастазів неколоректального і ненейроендокринного генезу базується на двох принципах: хірургія печінки стала більш безпечною завдяки оптимізації радіологічних методів діагностики та значно покращеній хірургічній техніці, а також внаслідок підвищення ефективності хіміо- та таргетної терапії окремих пухлин неколоректальної зони. Вважається, що хірургія в алгоритмах комбінованого лікування хворих із метастазами в печінці неколоректального раку може відігравати ключову роль, а тому потребує подальших досліджень 3 метою покращення останніх.

Встановлено, що ширина відступу від краю метастазу під час резекції $>0,5-1$ см асоціюється із кращими результатами лікування. Проте, за даними досліджень резекцій печінки при колоректальному раку, ширина відступу від краю метастазу не відіграє ролі, тоді як статус резекції R1-R2 визначає достовірно гірші віддалені результати лікування у порівнянні iз R0 [8]. Отже, можна вважати, що відступ від краю метастазу при резекціях $>1$ мм $є$ задовільним хірургічним результатом. Крім того, у хворих із білобарними чи множинними метастазами слід дотримуватися принципу максимального збереження паренхіми печінки з мінімальним відступом від краю пухлини. Циторедуктивна хірургія у таких пацієнтів є темою для активних дебатів, оскільки ії проведення не продемонструвало покращення віддалених результатів [9]. Одним з аргументів проти застосування циторедуктивної хірургії у хворих з метастазами

Таблиця 2. Кумулятивна виживаність та медіана виживаності досліджуваних груп хворих

\begin{tabular}{lccc}
\hline Групи хворих & Усього (n) & $\begin{array}{c}\text { Середнє значення } \\
\text { виживаності (міс) } \pm \\
\text { стандартна похибка }\end{array}$ & $\begin{array}{c}\text { Середнє значен- } \\
\text { нодіани вижива- } \\
\text { ності (міс) } \pm \text { стан- } \\
\text { дартна похибка }\end{array}$ \\
\hline Онкогінекологічна & 78 & $60,02 \pm 6,97$ & $86,52 \pm 0,0$ \\
Інші & 38 & $61,51 \pm 21,03$ & $22,42 \pm 9,63$ \\
Рак молочної за- & 72 & $43,98 \pm 3,95$ & $52,03 \pm 12,65$ \\
лози & 70 & $48,34 \pm 6,43$ & 0 \\
Рак шлунка & 29 & $43,17 \pm 7,13$ & $50,98 \pm 18,38$ \\
Онкоурологічна & 287 & $59,52 \pm 6,97$ & $44,78 \pm 5,58$ \\
Усього & & & \\
\hline
\end{tabular}


в печінці неколоректального раку є швидке прогресування хвороби після таких втручань, за винятком метастатичного раку молочної залози [10] та гінекологічних й урологічних злоякісних новоутворень [11], оскільки ефективність системної хіміотерапії дозволяє покращити виживаність, незважаючи на відсутність хірургічного радикалізму.

На нашу думку, декомпенсована супутня патологія, наявність інвазії метастазів у магістральні судини та об’єм майбутньої культі печінки <30\% після виконання резекціїє протипоказанням до виконання резекції у таких хворих. За даними деяких авторів, планування циторедуктивних оперативних втручань з приводу метастазів неколоректального раку має супроводжуватися ретельними СКТ- та МРТ-обстеженнями, а також мультидисциплінарним розбором за участю провідних хірургів-гепатологів. У хворих із метастазами в печінці хіміорезистентних пухлин (меланома чи рак нирки) резекції слід застосувати лише у випадку можливості радикального видалення як єдиного прийнятного методу без призначення хіміотерапії. Наявність позапечінкового метастатичного ураження черевної порожнини є відносним протипоказанням до виконання резекції печінки.

На основі отриманих результатів та даних літератури можемо стверджувати, що наявність позапечінкових сайтів метастичного ураження $є$ абсолютним протипоказанням до виконання резекції печінки, і лише в окремих роботах стверджується, що можливість виконання R0-резекції є вагомим показанням до їі застосування. Крім того, ключовим фактором, що впливає на рівень 5-річної виживаності серед всіх оперованих пацієнтів, вважаємо локалізацію первинноі пухлини та її гістологічний підтип [12]. За даними метааналізу, найгірший прогноз мали хворі із метастазами раку шлунковокишкового тракту, крім пацієнтів з раком шлунка.

\section{ВИСНОВКИ}

Резекції печінки у хворих із ненейроендокринними та неколоректальними пухлинами є доцільними та безпечними. Віддалені результати є морфологічно залежними. Проте ми не можемо рекомендувати рутинно виконувати оперативне лікування досліджуваним хворим. Селекція до резекцій печінки у хворих із ненейроендокринними та неколоректальними пухлинами повинна включати оцінку ефективності системного доопераційного лікування, статус хворого та розбір мультидисциплінарною командою у рамках спеціалізованого хірургічного центру.

\section{СПИСОК ВИКОРИСТАНОÏ ЛІТЕРАТУРИ}

1. Oki E., Ando K., Nakanishi R. etal. (2018) Recentadvances in treatment for colorectal liver metastasis. Ann. Gastroenterol. Surg., 2(3): 167-175. doi:10.1002/ags3.12071

2. Spolverato G., Bagante F., Aldrighetti L. et al. (2017) Neuroendocrine liver metastasis: prognostic implications of primary tumor site on patients undergoing curative intent liver surgery. J. Gastrointest. Surg., 21(12): 2039-2047. doi: 10.1007/s11605-017-3491-1.

3. Sim D.P.Y., Goh B.K.P., Lee S.Y. et al. (2018) Preoperative prognostic factors after liver resection for non-colorectal, non-neuroendocrine liver metastases and validation of the adam score in an asian population. World J. Surg., 42(4): 1073-1084. doi: 10.1007/s00268-017-4208-z.

4. Uggeri F., Ronchi P.A., Goffredo P. et al. (2015) Metastatic liver disease from non-colorectal, non-neuroendocrine, non-sarcoma cancers: a systematic review. World J. Surg. Oncol., 13: 191

5. Adam R., Pascal G., Azoulay D. et al. (2003) Liver resection for colorectal metastases: the third hepatectomy. Ann. Surg., 238(6): 871-883.

6. Fong Y., Fortner J., Sun R.L. et al. (1999) Clinical score for predicting recurrence after hepatic resection for metastatic colorectal cancer: analysis of 1001 consecutive cases. Ann. Surg., 230(3): 309-318.

7. Verhoef C., Kuiken B.W., ljzermans J.N., De Wilt J.H. (2007) Partial hepatic resection for liver metastases of non-colorectal origin, is it justified? Hepatogastroenterology, 54(77): 1517-1521.

8. Lendoire J., Moro M., Andriani O. et al. (2007) Liver resection for noncolorectal, non-neuroendocrine metastases: analysis of a multicenter study from Argentina. HPB (Oxford), 9(6): 435-439.

9. Rutkowski P., Nyckowski P., Grzesiakowska U. et al. (2003) The clinical characteristics and the role of surgery and imatinib treatment in patients with liver metastases from c-Kit positive Gastrolntestinal Stromal Tumors (GIST). Neoplasma, 50(6): 438-442.

10. Adam R., Chiche L., Aloia T. et al. (2006) Hepatic resection for noncolorectal nonendocrine liver metastases: analysis of 1452 patients and development of a prognostic model. Ann. Surg., 244: 524-535.

11. Slotta J.E., Schuld J., Distler S. et al. (2014) Hepatic resection of noncolorectal and non-neuroendocrine liver metastases-survival benefit for patients with nongastrointestinal primary cancers - a case-controlled study. Int. J. Surg., 12: 163-168.
12. Uggeri F., Ronchi P.A., Goffredo P. et al. (2015) Metastatic liver disease from non-colorectal, non-neuroendocrine, non-sarcoma cancers: a systematic review. World J. Surg. Oncol., 13: 191. DOI 10.1186/s12957-015-0606-6.

\section{Хирургическая тактика при неколоректальных и ненейроэндокринных метастатических поражениях печени \\ А.А. Бурлака}

\section{Национальный институт рака, Киев}

Резюме. До сих пор малоизучена эффективность оперативного лечения метастатического поражения печени неколоректальным раком и опухолями ненейроэндокринного генеза (рак почки, мочевого пузыря, яичка, матки и придатков, желудка, пищевода, тонкой кишки, легкого, меланома кожи), гематогенное метастазирование которых не ограничиваются только системой портальной вены, а распространяется с системным кровотоком. Цель. Выполнить ретроспективный анализ эффективности и безопасности резекции печени у больных с метастазами неколоректального и ненейроэндокринного генеза. Объект и методы. Нами проведен ретроспективный анализ результатов комбинированного лечения онкологических больных, имеющих в анамнезе метастатическое поражение печени, на основе базы данных Национального канцер-регистра Национального института рака. Результаты. Ретроспективно изучено 287 случаев хирургического и комбинированного лечения больных онкологического профиля, которые имели метастатическое поражение печени. Пациентов условно стратифицировали на 5 групп по морфологическим данным. Наибольшую долю этой когорты составили пациенты с онкогинекологическим генезом первичных опухолей $(n=78 ; 27,2 \%)$, больные раком молочной железы $(n=72 ; 25,1 \%)$ и группа больных раком желудка $(n=70 ; 24,4 \%)$. Меньше больных было в онкоурологической группе $(\mathrm{n}=29 ; 10,1 \%)$. Также мы проанализировали результаты выполнения 38 (13,3\%) резекций печени, первичные опухоли которых имели различную локализацию и гистологическое строение, в частности рак гортани, трахеи, легкого, языка (другие). Медиана общей выживаемости составила: онкогинекологическая группа $-86,52 \pm 0,0 \mathrm{меc,}$

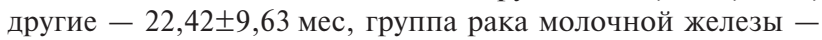
$52,03 \pm 12,65$ мес, группа рака желудка - 0 мес, онкоурологическая группа - 50,98土18,38 мес. Выводы. Резекции печени у больных с ненейроэндокринными и неколоректальными опухолями являются целесообразными и безопасными. Отдаленные результаты являются морфологически зависимыми. Селекция в резекции печени у больных с ненейроэндокринными и неколоректальными опухолями должна включать оценку эффективности системного дооперационного лечения, статус больного и разбор мультидисциплинарной командой в специализированных хирургических центрах.

Ключевые слова: резекция печени; неколоректальное метастатическое поражение; выживаемость.

\section{Surgical tactic for non-colorectal and non-neuroendocrine liver metastases} A.A. Burlaka

National Cancer Institute, Kyiv

Summary. The efficacy of surgical treatment of metastatic liver damage with non-colorectal cancer and non-neuroendocrine tumors (kidney, bladder, testicular, uterus and appendages, stomach, esophagus, small intestine, lung, skin melanoma) whose pathways of hematogenous metastasis are not limited to the system of portal vein, and spread with systemic blood flow stay still unknown. Aim. Perform a retrospective analysis of the efficacy and safety of liver resections in patients with non-colorectal and non-neuroendocrine metastases. Material and methods. We conducted a retrospective analysis of the results of combined treatment patients who had a metastatic liver injury during the history of the disease based on the National Cancer Registry database of the National Cancer Institute. Results. A retrospective study of 287 cases of surgical 
and combined treatment of cancer patients who had metastatic liver damage. The largest share of this cohort was made up of patients with oncogynecological origin of primary tumors $(n=78$; $27.2 \%)$, patients with breast cancer $(n=72 ; 25.1 \%)$ and a group of patients with gastric cancer $(n=70 ; 24.4 \%)$. The least patients were in the oncourological group $(n=29 ; 10.1 \%)$. We also analyzed the results of $38(13.3 \%)$ resections of the liver, whose primary tumors had a different localization and histological structure, in particular, laryngeal, trachea, lung, tongue (others). The median of overall 5-year survival was: oncogynecological group $86.52 \pm 0.0$ months, others $-22.42 \pm 9.63$ months, breast cancer group $-52.03 \pm 12.65$ months, gastric cancer group -0 months, oncourological group $-50.98 \pm 18.38$ months. Conclusions. Resection of the liver in patients with non-neuroendocrine and non-colorectal tumors is appropriate and safe. Long-term results are morphologically dependent. Selection for resection of the liver in patients with non-neuroendocrine and non-colorectal tumors should include the evaluation of the effectiveness of systemic preoperative treatment, the status of the patient and the analysis of a multidisciplinary team in the specialized surgical centers.

Key words: liver resection; non-colorectal metastases; overall survival.

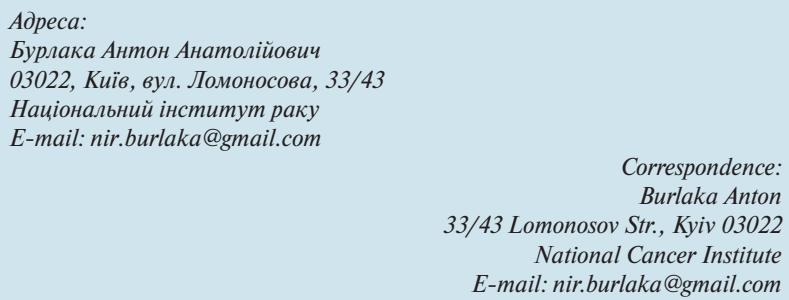

